\title{
Herbicides selectivity on seedlings of White Leadtree (Leucaena leucocephala)
}

\section{Seletividade de herbicidas em mudas de Leucena (Leucaena leucocephala)}

\author{
Roque Carvalho DIAS ${ }^{1}$; Diego Munhoz GOMES ${ }^{2}$; Vitor Muller ANUNCIATO ${ }^{3}$; Leandro BIANCHI ${ }^{3}$; \\ Caio Antonio CARBONARI ${ }^{3}$; Edivaldo Domingues VELINI ${ }^{3}$
}

\begin{abstract}
${ }^{1}$ Autor para correspondência: Eng. Agr., Doutorando em Agronomia (Proteção de Plantas), Universidade Estadual Paulista (Unesp), Faculdade de Ciências Agronômicas, Departamento de Proteção de Plantas, Av. Universitária, $n^{\circ} 3780$ - Altos do Paraíso, 18610-034 , Botucatu - SP, e-mail: roquediasagro@gmail.com

${ }^{2}$ Graduando em Engenharia Florestal, Universidade Estadual Paulista (Unesp), Faculdade de Ciências Agronômicas, Botucatu - SP, e-mail: diegomgomes77@gmail.com

${ }^{3}$ Eng. Agr., Doutorando em Agronomia (Proteção de Plantas), Universidade Estadual Paulista (Unesp), Faculdade de Ciências Agronômicas, Botucatu - SP, e-mail: vitor.muller@gmail.com

${ }^{4}$ Eng. Agr., Doutorando em Agronomia (Proteção de Plantas), Universidade Estadual Paulista (Unesp), Faculdade de Ciências Agronômicas, Botucatu - SP, e-mail: leandro_bianchii@hotmail.com

${ }^{5}$ Docente do Departamento de Produção e Melhoramento Vegetal da Universidade Estadual Paulista (Unesp), Faculdade de Ciências Agronômicas, Botucatu - SP, e-mail: carbonari@fca.unesp.br

${ }^{6}$ Docente do Departamento de Produção e Melhoramento Vegetal da Universidade Estadual Paulista (Unesp), Faculdade de Ciências Agronômicas, Botucatu - SP, e-mail: velini@fca.unesp.br
\end{abstract}

\section{Recebido em: 30-10-2019; Aceito em: 09-01-2020}

\begin{abstract}
Difficulty in controlling weeds has hindered the success of vegetation recovery projects using white leadtree (Leucaena leucocephala) seedlings in degraded areas. The use of herbicides is indispensable to mitigate damage and make these areas viable. Therefore, this study evaluated the selectivity of pre- and postemergence herbicides on white leadtree seedlings. Two experiments were carried out in a greenhouse in a randomized block design with four replications. Pre-emergence treatments $\left(\mathrm{g} \mathrm{ha}^{-1}\right)$ were: atrazine $(3,500.00)$, chlorimuron-ethyl (20.00), clomazone (900.00), flumioxazin (125.00), indaziflam (100.00), isoxaflutole (262.50), pendimethalin $(1,150.00)$, sulfentrazone $(500)$, and S-metolachlor $(1,920.00)$, in addition to a control (without herbicide). The second experiment consisted of the following postemergence treatments ( $\left.\mathrm{g} \mathrm{ha}^{-1}\right)$ : atrazine $(2,500.00)$, chlorimuron-ethyl (15.00), clomazone (54.00), flumioxazin (20.00), glyphosate (396.25), haloxyfop-methyl (49.88), indaziflam (75.00), isoxaflutole (187.50), pendimethalin $(1,150.00)$, and S-metolachlor $(1,440.00)$, in addition to a control (without herbicide). Phytotoxicity, plant height, and root collar diameter were assessed at 3, 7, 14, 30, and 60 days after application (DAA). Shoot dry matter was assessed at 60 DAA. Herbicides atrazine, indaziflam, and isoxaflutole, applied in pre- and postemergence, in addition to glyphosate, negatively influenced all evaluations, being considered nonselective for white leadtree plants. Herbicides with selectivity, regardless of the application method, were chlorimuron-ethyl, clomazone, flumioxazin, haloxyfop-methyl, pendimethalin, sulfentrazone, and S-metolachlor.
\end{abstract}

Additional keywords: forest restoration; phytotoxicity; recovery of degraded areas; reforestation; selective herbicides.

\section{Resumo}

Um dos entraves ao sucesso dos projetos de recuperação da vegetação em áreas degradadas utilizando mudas de leucena (Leucaena leucocephala) tem sido a dificuldade de controle de plantas daninhas. O uso de herbicidas é uma prática indispensável para atenuar e viabilizar essas áreas. Diante disso, objetivou-se avaliar a seletividade de herbicidas aplicados em pré e pós-emergência sobre mudas de leucena. Realizou-se dois experimentos em casa de vegetação, em delineamento em blocos casualizados com quatro repetições. Os tratamentos utilizados foram aplicados em pré-emergencia $\left(\mathrm{g} \mathrm{ha}^{-1}\right)$ : atrazine $(3.500,00)$, chlorimuron-ethyl $(20,00)$, clomazone $(900,00)$, flumioxazin $(125,00)$, indaziflam $(100,00)$, isoxaflutole $(262,50)$, pendimethalin $(1.150,00)$, sulfentrazone (500) e S-Metolachlor (1.920,00), além de um controle (sem herbicida). No segundo experimento, aplicou-se em pós-emergência $\left(\mathrm{g} \mathrm{ha}^{-1}\right)$ : atrazine $(2.500,00)$, chlorimuron-ethyl $(15,00)$, clomazone $(54,00)$, flumioxazin $(20,00)$, glyphosate $(396,25)$, haloxyfop-methyl $(49,88)$, indaziflam $(75,00)$, isoxaflutole $(187,50)$, pendimethalin $(1.150,00)$ e S-Metolachlor (1.440,00), além de um controle (sem herbicida). Foram realizadas aos 3, 7, 14, 30 e 60 dias após a aplicação (DAP) avaliações de fitointoxicação, altura, diâmetro do coleto e aos 60 DAP a biomassa seca da parte aérea. Os herbicidas atrazine, indaziflam e isoxaflutole em pré e pós-emergência, além do glyphosate, influenciaram negativamente em todas as avalições realizadas, sendo considerados não seletivos para as 
plantas de leucena. Os herbicidas que apresentaram potencial de seletividade, independentemente da modalidade de aplicação, foram o chlorimuron-ethyl, clomazone, flumioxazin haloxyfop-methyl, pendimethalin, sulfentrazone e S-Metolachlor.

Palavras-chave adicionais: fitointoxicação; herbicidas seletivos; recuperação de áreas degradadas; reflorestamentos; restauração florestal.

\section{Introduction}

The growing demand for services aimed at the recovery of degraded and/or disturbed areas, restoration of riparian forests, and afforestation makes necessary the use of low-cost and good-quality seedlings for the best development and field survival percentage of plants. In this sense, white leadtree [Leucaena leucocephala (Lam.) R. de Wit.] stands as an option for rapid growth, with a deep root system that provides great tolerance to drought, great capacity for nitrogen fixation, and versatility in its use. However, weed interference draws attention both to the plant species intended for forest restoration and to economic issues, since these plants compete for water, light, and nutrients (Machado et al., 2013). Hence, weed control is one of the main challenges of forest restoration, with the cultural treatments necessary in the initial stages of reforestation being of paramount importance (Maciel et al., 2011), since inadequate control during the first years after planting can limit the growth and establishment of reforestation species (Souza et al., 2010).

Chemical weed control is considered an effective, fast, and economically viable alternative in species intended for forest restoration (Brancalion et al., 2009). It should be emphasized that most studies on herbicide selectivity focus on the cultivation of eucalyptus and pine (Monquero et al., 2011), and that there is little research involving these molecules in other reforestation species. Moreover, differentiated selectivity over some studied species can be another factor in choosing the herbicide.

The identification of herbicides selective to tree species such as $L$. leucocephala would enable the use of more practical and effective methods of weed control, with potential use in forest restoration programs, commercial plantations, and agroforestry systems. Thus, this study evaluated the selectivity of pre- and postemergence herbicides on L. leucocephala plants.

\section{Materials and methods}

Two experiments were carried out in a greenhouse (average temperature of $28{ }^{\circ} \mathrm{C}$, relative humidity of $70 \%$, and natural light) in a completely randomized design with four replications, from December 2018 to April 2019. Experiments 1 and 2 (E1 and E2) constituted the evaluation of pre- and postemergence herbicides, respectively. Seeds of $L$. leucocephala were placed to germinate using a moistened germitest paper roll as a substrate. After germination, the seedlings were transplanted to $800 \mathrm{~cm}^{3}$ polyethylene pots, placing one plant in each container. Herbicides were applied 35 days after transplanting, and the pots were irrigated to maintain the moisture necessary for good plant development.

For experiment 1 (pre-emergence herbicides), the soil used in the experimental units was collected in the arable layer of 0.0 to $0.2 \mathrm{~m}$, being classified as Red Yellow Latosol (Embrapa, 2013), with the following physicochemical characteristics: sand, clay, and silt: 695, 185, $119 \mathrm{~g} \mathrm{~kg}^{-1}$, respectively; organic matter, $23 \mathrm{~g} \mathrm{dm}^{-3} ; \mathrm{pH} \quad\left(\mathrm{CaCl}_{2} 0.01 \mathrm{~mol} \mathrm{~L}^{-1}\right), 6.8 ; \mathrm{P}_{\text {(resin) }}$, $310 \mathrm{mg} \mathrm{dm}^{-3} ; \mathrm{K}, \mathrm{Ca}, \mathrm{Mg}$, and $\mathrm{H}+\mathrm{Al}: 1.70,85.00,35.00$, and $7.00 \mathrm{mmol}_{\mathrm{c}} \mathrm{dm}^{-3}$, respectively; and base saturation of $81 \%$.

Treatments were applied directly to the soil with the aid of microsyringes. The amount of herbicide solution to be placed per experimental unit was determined according to the area of the container and the dose used per hectare. Treatments including preemergence herbicides and their respective doses were as follows ( $\left.\mathrm{g} \mathrm{ha}^{-1}\right)$ : atrazine $(3,500.00)$, chlorimuronethyl (20.00), clomazone (900.00), flumioxazin (125.00), indaziflam (100.00), isoxaflutole (262.50), pendimethalin $(1,150.00)$, sulfentrazone (500), and S-metolachlor $(1,920.00)$, in addition to a control (without herbicide).

The experimental units of experiment 2 (postemergence herbicides) were filled with substrate Carolina II, composed of sphagnum peat, expanded vermiculite, roasted rice husk, dolomitic limestone, agricultural gypsum, and NPK traces. The substrate had the following physicochemical characteristics: electrical conductivity $(\mathrm{EC})=0.7 \pm 0.3 \mathrm{mS} \mathrm{cm}^{-1} ; \mathrm{pH}$ $\left(\mathrm{H}_{2} \mathrm{O}\right.$ or $\left.\mathrm{KCl}\right), 5.5 \pm 0.5$; particle density of $155 \mathrm{~kg} \mathrm{~m}^{-3}$; and water holding capacity of $55 \%$.

Treatments were applied using a sprayer installed in a closed environment, equipped with a spray bar with four XR 110.02 VS nozzles spaced $0.5 \mathrm{~m}$ apart and positioned $0.5 \mathrm{~m}$ above the surface of the experimental units. The system was operated with a displacement speed of $3.6 \mathrm{~km} \mathrm{~h}^{-1}$, syrup volume of $200 \mathrm{~L} \mathrm{ha}^{-1}$, and constant compressed air pressure of $294,3 \mathrm{kPa}\left(3.0 \mathrm{kgf} \mathrm{cm}^{-2}\right)$. The herbicides used were (g ha $\left.{ }^{-1}\right)$ : atrazine $(2,500.00)$, chlorimuron-ethyl (15.00), clomazone (54.00), flumioxazin (20.00), glyphosate (396.25), haloxyfop-methyl (49.88), indaziflam (75.00), isoxaflutole (187.50), pendimethalin $(1,150.00)$, and Smetolachlor $(1,440.00)$, in addition to a control (without herbicide).

The variables analyzed in both experiments were phytotoxicity, shoot height, root collar diameter, and shoot dry matter. Phytotoxicity was evaluated at 3, $7,14,30$, and 60 days after application (DAA) through a grade scale in which $0 \%$ represents no damage and 
$100 \%$ represents plant death according to the methodology proposed by SBCPD (1995). Seedling shoot height (from root collar until the last expanded leaf) was measured with the aid of a ruler graduated in millimeters. Root collar diameter was measured with a caliper (next to the seedling neck). The growth in height and diameter were obtained by the difference between seedling length in the installation of the experiment and in each evaluation period for each replicate in each treatment.

Shoots of white leadtree seedlings were cut close to the soil at 60 DAA, being taken to a greenhouse with forced air circulation at constant temperature $\left(70^{\circ} \mathrm{C}\right)$ for 72 hours to determine the dry matter.

Data were submitted to analysis of variance ( $p \leq 0.05$ ) with the aid of Sisvar ${ }^{\circledR}$ software (Ferreira, 2008), and the graphs were prepared by Sigmaplot version 12.5 .

\section{Results and discussion}

Among pre-emergence herbicides, flumioxazin, pendimethalin, sulfentrazone, and S-metolachlor did not cause visual damage in all evaluated periods, demonstrating a high selectivity of these molecules to white leadtree seedlings (Figure 1A). The mechanism of action of herbicides flumioxazin and sulfentrazone is based on the inhibition of the enzyme protoporphyrinogen oxidase (PROTOX), these herbicides having a contact action in the sprayed plants (Oliveira Jr., 2011). Nevertheless, although they have the same mechanism of action, flumioxazin controls monocotyledons, while sulfentrazone effectively controls monocotyledons and eudicotyledons.

When working with a different reforestation species açoita-cavalo (Luehea divaricata), Monquero et al. (2011) also reported selectivity for the herbicide sulfentrazone. Similarly, under the same doses of this experiment, flumioxazin and sulfentrazone did not cause phytotoxicity on eucalyptus plants after 30 DAA (Tiburcio et al., 2012). Pendimethalin, in turn, inhibits cell division, preventing tubulin polymerization and inhibiting root growth and the formation of secondary roots, being used for the control of monocotyledonous and some eudicotyledonous weeds (Oliveira Jr., 2011). Pre-emergence application of pendimethalin (500, 1000 , and $2000 \mathrm{~g}$ a.i. $\mathrm{ha}^{-1}$ ) did not affect the emergence and initial development of carcuera (Platypodium elegans) and carobinha (Jacaranda micrantha) (Marchi et al., 2018), having similar effects on jatoba (Hymenaea stigonocarpa) and annatto (Bixa orellana) $(500,1000$, and $4000 \mathrm{~g}$ a.i. ha-1) (Marques et al., 2019).

A

3 DAA שII 7 DAA $\square \square$ 14 DAA $\square / \triangle 30$ DAA $\square 60$ DAA

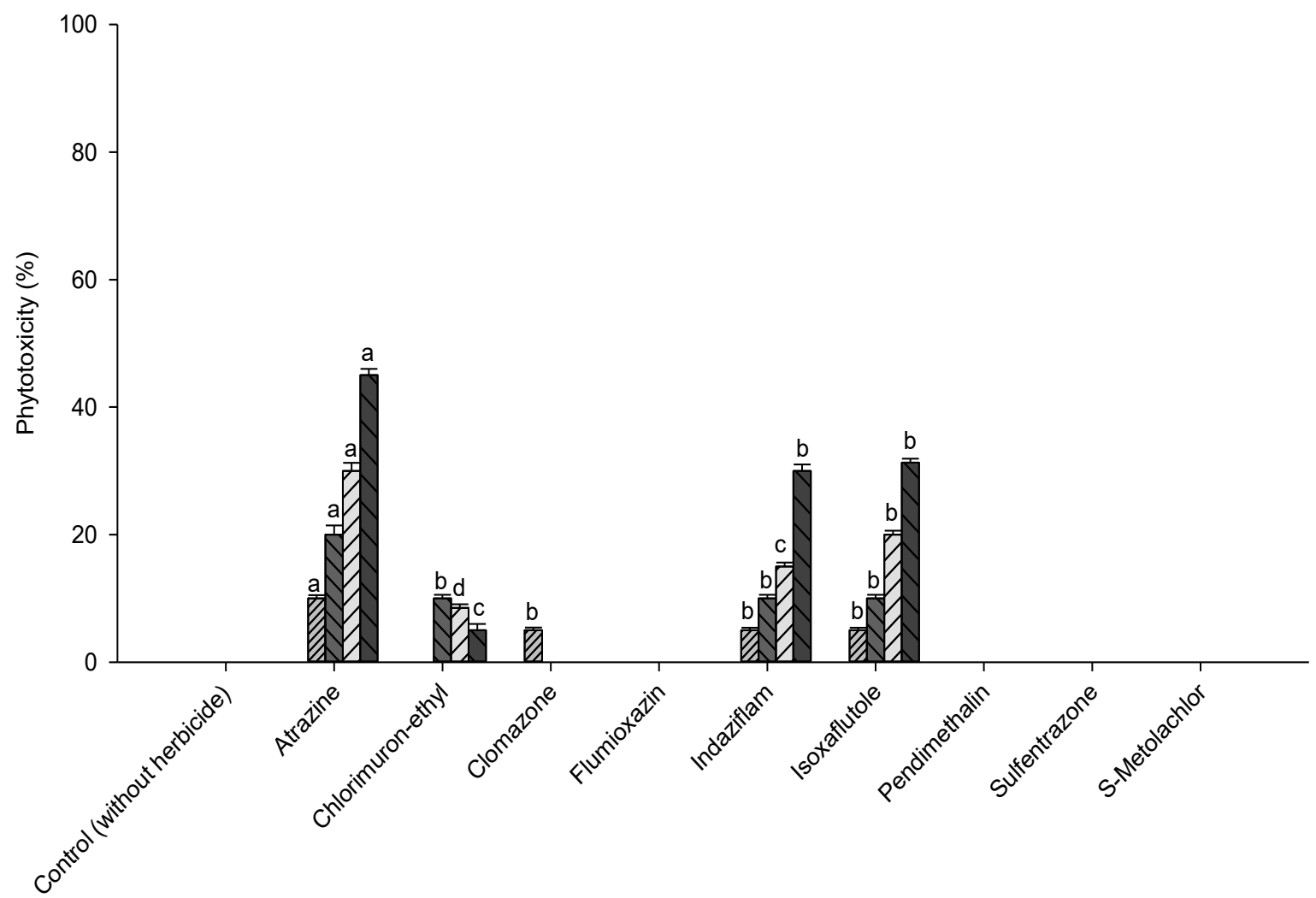


B 3 DAA $\square=7$ DAA $\square 14$ DAA $\square / \triangle 30$ DAA $\square 60$ DAA

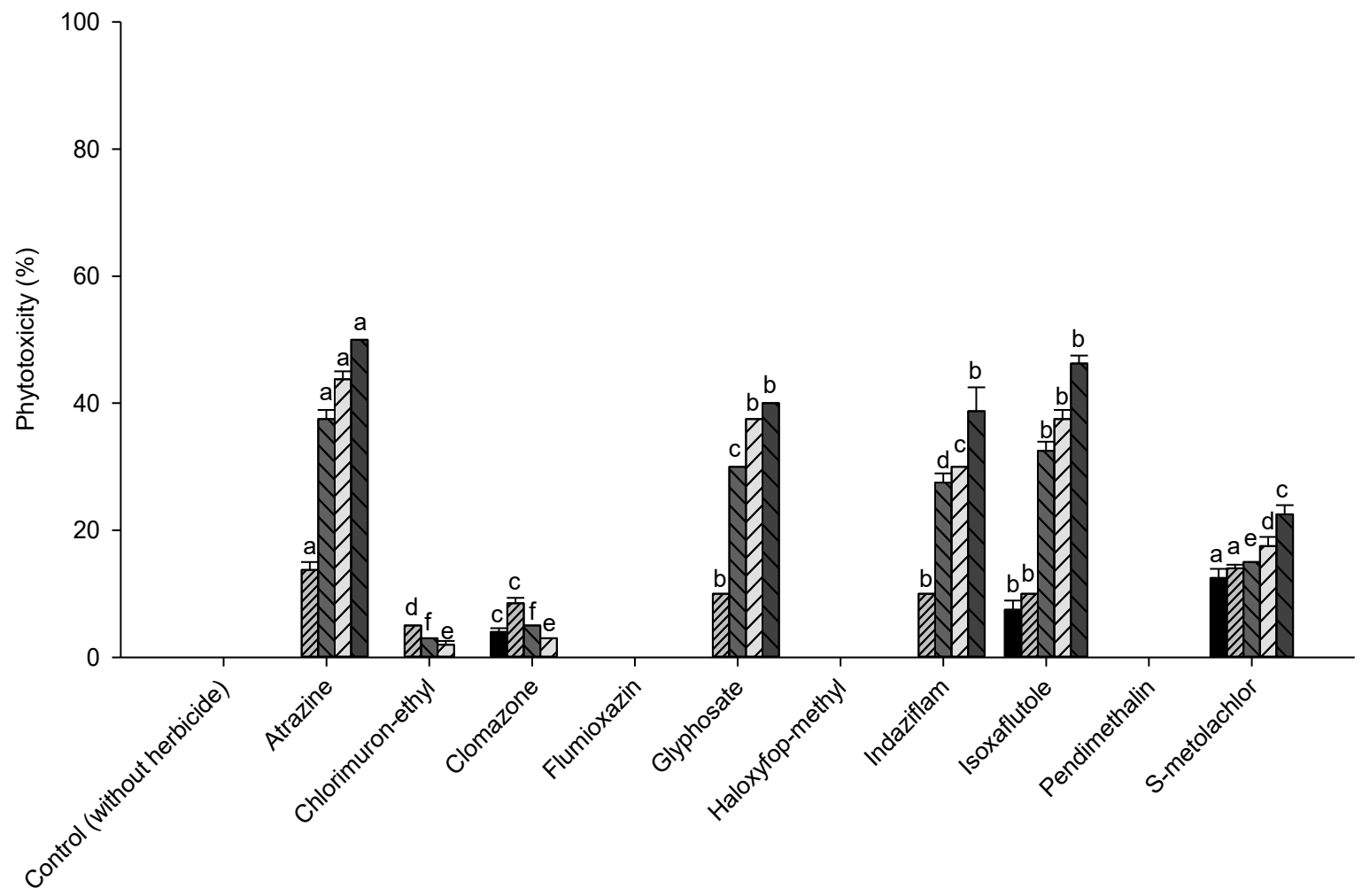

Figure 1 - Phytotoxicity (\%) of applied herbicides in pre (A) and post-emergence (B) on white leadtree (Leucaena leucocephala) seedlings.

Means followed by the same letter in each column do not differ according to the Scott-Knott grouping criterion at $5 \%$ probability. Vertical bars represent the standard deviation of the means.

The highest values of phytotoxicity were observed, respectively, for atrazine (45\%), isoxaflutole, and indaziflam (Figure 1A). According to Ferreira et al. (2005), atrazine caused different symptoms in tree species, such as seedlings with chlorosis followed by necrosis, malformed cotyledons, and reduced plant emergence, emphasizing criteria for its use. For isoxaflutole, Marchi et al. (2018) found reductions in the number of seedlings and leaves in mutamba (Guazuma ulmifolia), carobinha (J. micrantha), and angico (Anadenanthera colubrina) under the dose of $300 \mathrm{~g}$ a.i. ha- ${ }^{-1}$. Still regarding isoxaflutole, Brighenti \& Muller (2014) found greater phytotoxic effects in doses lower than those used in this study in African mahogany (Khaya ivorensis) and Australian cedar (Toona ciliata var. australis) seedlings. Isoxaflutole belongs to the group of carotenoid biosynthesis herbicides, which are essential in the protection of chlorophyll against degradation by sunlight, with bleaching of photosynthetic tissues being a common symptom (Oliveira Jr., 2011). Thus, it is emphasized that herbicides that cause symptoms of more intense visual damage in plants can negatively influence plant growth and development, which makes their use unfeasible.
When analyzing postemergence treatments applied to white leadtree plants (Figure 1B), no visual symptoms of phytotoxicity were observed in all periods evaluated for herbicides flumioxazin and pendimethalin, with similar results when applied in preemergence. White leadtree plants treated with the herbicide haloxyfop-methyl also showed no symptoms of phytotoxicity (Figure 1A).

When studying the selectivity of herbicides in aroeira (Myracrodruon urundeuva), Duarte et al. (2006) found that haloxyfop-methyl $(0,120,240$, and $480 \mathrm{~g}_{\text {a.i. }} \mathrm{ha}^{-1}$ ) and the herbicide sulfentrazone, which has the same mechanism of action as flumioxazin, did not cause symptoms of phytotoxicity. Likewise, postemergence application of herbicides flumioxazin and sulfentrazone on eucalyptus plants did not cause symptoms of phytotoxicity after 30 DAA (Tiburcio et al., 2012). Moreover, pendimethalin application in carcuera ( $P$. elegans), carobinha (J. micrantha) (Marchi et al., 2018), jatoba ( $H$. stigonocarpa), and annatto (B. orellana) (Marques et al., 2019) did not affect the development of treated plants. The primary mode of action of haloxyfop-methyl is to inhibit the synthesis of fatty acids by inhibiting the enzyme Acetyl Coenzyme- 
A Carboxylase (ACCase), being a specific herbicide for control of grasses (Oliveira Jr., 2011). These results demonstrate the selectivity of these herbicides combined with the broad spectrum of weed control.

Similar to pre-emergence application of herbicides chlorimuron-ethyl and clomazone, their postemergence application led to mild initial symptoms of toxicity $(\leq 8.5 \%)$, which dissipated during the experiment, followed by recovery of the treated plants. Brighenti \& Muller (2014) did not see toxicity in African mahogany plants after application of chlorimuron-ethyl (7.5 and $12.5 \mathrm{~g}$ a.i. ha- ${ }^{-1}$. Forest species such as ingabeans (Inga marginata), pau-ferro (Caesalpinia ferrea), and brauna-do-sertão (Schinopsis brasiliensis) showed tolerance to the herbicide clomazone (Cabral et al., 2017).

On the other hand, atrazine, glyphosate, indaziflam, isoxaflutole, and S-metolachlor caused higher levels of visual phytotoxicity compared to the herbicides studied in postemergence. The highest symptom values were observed for atrazine at 60 days after application (DAA) (up to $50 \%$ ), followed by isoxaflutole, glyphosate, indaziflam, and S-metolachlor (Figure 1A).

For atrazine, the symptoms were characterized by chlorosis and darkening of the edges of the leaves, leading to their fall. Ferreira et al. (2005) observed plant death in Solanum granuloso-leprosum when evaluating the initial development of tree species after application of the herbicide atrazine at the same dose used in this experiment $\left(2,500 \mathrm{~g}\right.$ a.i. ha- $\left.{ }^{-1}\right)$. In turn, isoxaflutole $\left(150 \mathrm{~g}\right.$ a.i. $\left.\mathrm{ha}^{-1}\right)$ led to reductions in the number of seedlings and leaves in mutamba (Guazuma ulmifolia), carobinha (J. micrantha), and cuiabano angico (Anadenanthera colubrina) (Marchi et al., 2018). When using isoxaflutole at the doses of 75 and $112.5 \mathrm{~g}$ a.i. ha- ${ }^{-1}$, phytotoxic values ranged from 15 to $28 \%$ in African mahogany, and from 29 to $34.2 \%$ in Australian cedar, respectively (Brighenti \& Muller, 2014).

Several studies have evaluated symptoms of phytotoxicity by glyphosate in arboreal, native, and reforestation species such as aroeira (Myracrodruon urundeuva) (Duarte et al., 2006); parica (Schizolobium amazonicum), kapok (Ceiba pentandra) (Yamashita et al., 2009); monjoleiro (Acacia polyphylla), tamboril (Enterolobium contortisiliquum), silk floss (Ceiba speciosa), açoita-cavalo (Luehea divaricata) (Monquero et al., 2011); vinhatico (Plathymenia reticulata), sucupira (Bowdichia virgilioides), pau-santo (Kielmeyera lathrophyton), lobeira (Solanum lycocarpum) (Machado et al., 2013); red aroeira (Schinus terebinthifolius), and yellow ipe (Handroanthus albus). The symptoms found are similar to those observed in the present study, characterized by burning in the youngest leaves followed by necrosis and fall.

A

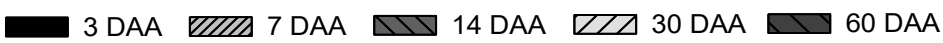

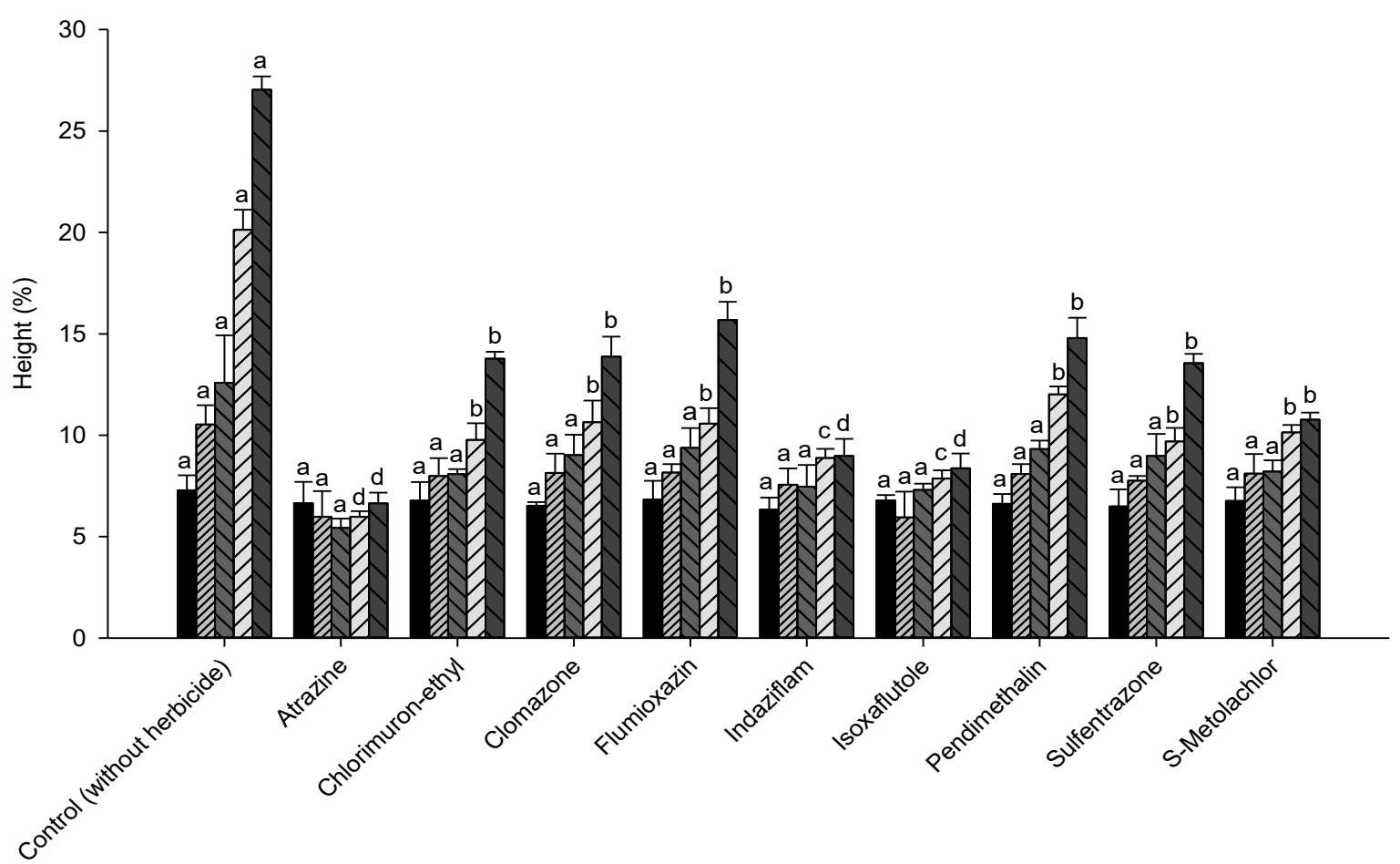




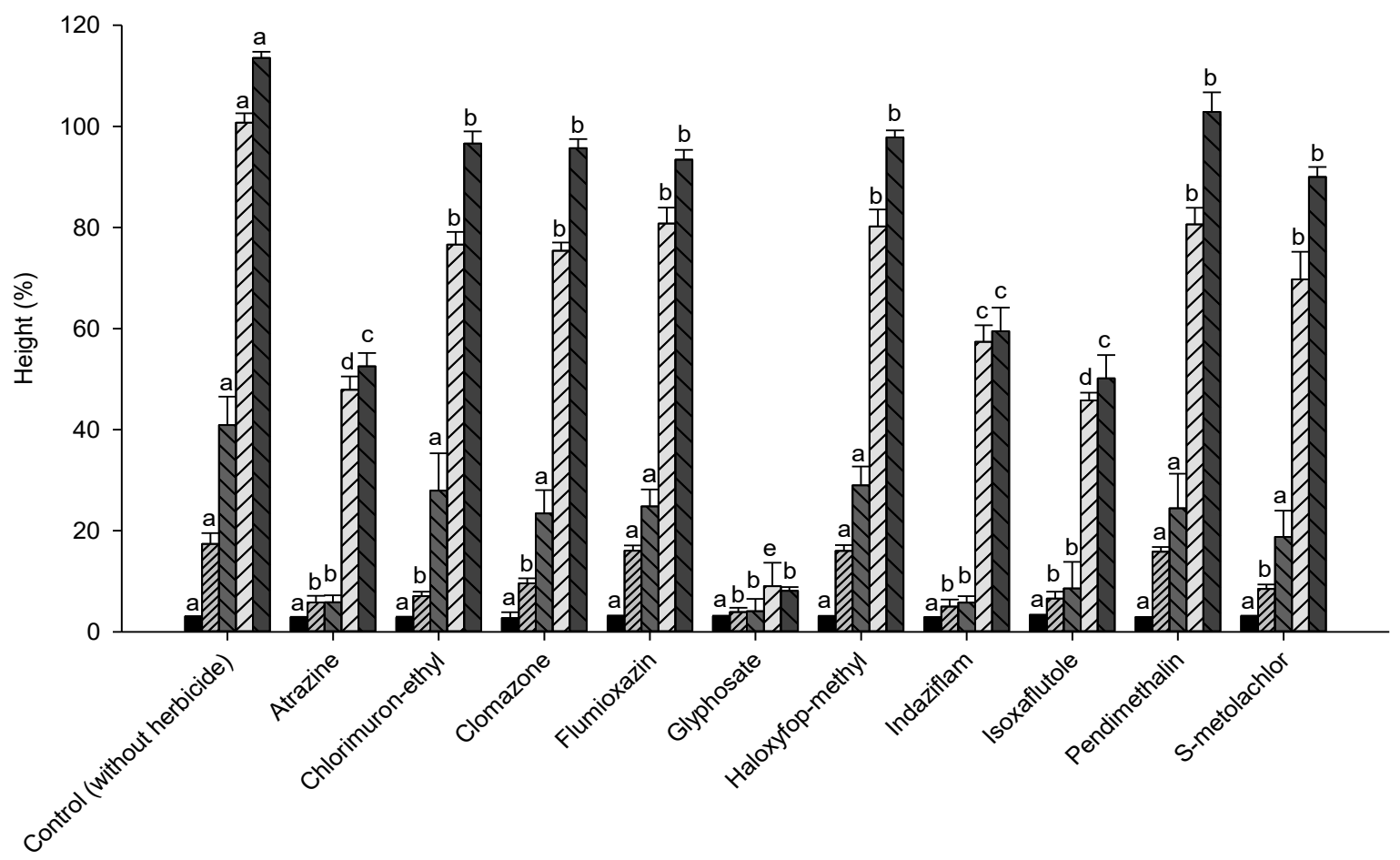

Figure 2 - Height (\%) of white leadtree (Leucaena leucocephala) seedlings under application of herbicides in pre (A) and post-emergence (B).

Means followed by the same letter in each column do not differ according to the Scott-Knott grouping criterion at $5 \%$ probability. Vertical bars represent the standard deviation of the means.

Moreover, a simulation of glyphosate drift (345.6 g a.e. ha $^{-1}$ ) on eucalyptus plants led to leathery, deformed leaves with well-developed necroses on the edges and necrotic spots by the leaf blade, in addition to the death of plant apices (Tuffi Santos et al., 2005). Leaf senescence is a characteristic symptom occurring after the absorption of low doses of glyphosate, as reported in studies with forest species under the drift effect of this product (Tuffi Santos et al., 2005; Yamashita et al., 2009).

For pre- and postemergence, atrazine, indaziflam, and isoxaflutole were the herbicides that most negatively influenced plant height in white leadtree seedlings. Reductions were up to 75.45 , 66.92 , and $69.04 \%$, respectively, for the first application method in relation to the control treatment (without herbicide) (Figure $2 \mathrm{~A}$ ), and $47.50,56.92$, and $45.44 \%$, for postemergence application (Figure $2 \mathrm{~B}$ ). The results corroborate with the data on phytotoxicity, demonstrating that there were irrecoverable losses on plant growth.

Ferreira et al. (2005) verified a decrease in the growth of tree species pau-cicada ( $S$. multijuga) and fedegoso ( $S$. macranthera) under the application of atrazine. In pre-emergence, Marchi et al. (2018) found a reduction in the height of seedlings of native Cerrado species such as mutamba (G. ulmifolia) and cuiabano angico
(A. colubrina) under the application of isoxaflutole (150 and $300 \mathrm{~g}$ a.i. ha ${ }^{-1}$ ). For that same herbicide, Marques et al. (2019) found reductions in the height of dry flour (Albizia hasslerii) (300 g a.i. ha-1) and white jurema (Mimosa interrupta) $(100,200$, and $300 \mathrm{~g}$ a.i. ha-1). Furthermore, post-emergence application of isoxaflutole $\left(150,300\right.$, and $600 \mathrm{~g}$ a.i. ha $\left.{ }^{-1}\right)$ reduced plant height in aroeira (M. urundeuva) (Duarte at al., 2006).

Herbicides chlorimuron-ethyl, clomazone, flumioxazin, pendimethalin, S-metolachlor, in both application modalities, in addition to sulfentrazone and haloxyfop-methyl, applied in pre- and postemergence, respectively, reduced plant height in a less intense way, as the plants recovered from symptoms throughout the evaluated periods (Figures 2A and 2B).

In pre-emergence application of clomazone in forest species such as inga-bean (I. marginata), caroba (J. puberula), and guanandi (Calophyllum brasiliensis) (Cabral et al., 2017), and pendimethalin in carcuera ( $P$. elegans), carobinha (J. micrantha) (Marchi et al., 2018), jatoba (H. stigonocarpa), annatto ( $B$. orellana), and dry flour $(A$. hasslerii) (Marques et al., 2019), the authors did not find a reduction in plant height. In postemergence application of haloxyfop-methyl in aroeira seedlings (Duarte et al., 2006), sulfentrazone in African 
mahogany (Paz et al., 2018), and flumioxazin and sulfentrazone in eucalyptus (Tiburcio et al., 2012), plant height did not decrease as well. These results corroborate with the phytotoxicity analysis, thus demonstrating that there was no negative influence on plant growth.

It is noteworthy that glyphosate was the herbicide that most affected the growth of treated plants throughout the evaluation periods, with reductions of up to $92.8 \%$ at 60 DAA (Figure 2A). Tuffi Santos et al. (2005) found a lower height in eucalyptus plants submitted to the drift effect of glyphosate (345.6 g a.e. ha-1). It is known that plant height decreased in the following plants after glyphosate application (a.e. ha-1): aroreia (720) (Duarte et al., 2006), parica (Schizolobium amazonicum), kapok (C. pentandra) (360) (Yamashita et al., 2009), and lobeira (S. lycocarpum) (160) (Machado et al., 2013). This high reduction is associated with the death of apical buds of plants treated with glyphosate, together with symptoms of toxicity, the presence of nonviable (abnormal) shoots, and leaf senescence.

Pre- and postemergence herbicides such as chlorimuron-ethyl, clomazone, flumioxazin, pendimethalin, and S-metolachlor, in addition to sulfentrazone (pre-emergence) and haloxyfopmethyl (postemergence), caused an initial reduction in plant diameter. Notwithstanding, similar to plant height, the values were re-established throughout the experimental period (Figure $3 \mathrm{~A}$ and $3 \mathrm{~B}$ ). The plant diameter values observed suggest great availability of photoassimilated compounds in the shoots. This availability indicates potential for seedling survival, growth, and greater adaptability, due to high capacity for formation and growth of new roots (Scalon et al., 2002). In forest species such as caroba (Jacaranda puberula), cedar (Cedrela fissilis), sibipiruna (Caesalpinia pluviosa), braunado-Sertão (S. brasiliensis), and guapuruvu (Schizolobium parahyba), plant diameter was not affected after application of clomazone (Cabral et al., 2017). In addition, when studying the pre-emergence application of pendimethalin, Marchi et al. (2018) found no diameter reductions in carcuera ( $P$. elegans) and carobinha (J. micrantha), the same being observed by Marques et al. (2019) in jatoba ( $H$. stigonocarpa), annatto ( $B$. orellana), and dry flour (A. hasslerii). Herbicides flumioxazin and sulfentrazone also did not reduce the diameter of eucalyptus plants (Tiburcio et al., 2012).

Reductions in diameter values in pre- and postemergence were up to 42.08 and $45.68 \%$ for atrazine, 11.46 and $43.89 \%$ for indaziflam, and 12.76 and $42.76 \%$ for isoxaflutole, respectively, at 60 DAA (Figures $3 A$ and 3B). In tree species such as pau-cicada (Senna multijuga), fedegoso (S. macranthera), and $S$. granuloso-leprosum, atrazine application decreased the diameter of plants (Ferreira et al., 2005), the same being observed in native Cerrado species such as mutamba (G. ulmifolia) and cuiabano angico ( $A$. colubrina) under isoxaflutole application (Marchi et al., 2018).

Glyphosate was the herbicide that most decreased the diameter of white leadtree plants, with a $47.22 \%$ reduction at 60 DAA (Figure $3 A$ ). Likewise, Machado et al. (2013) noticed a decrease in the diameter at collar height of Solanum lycocarpum plants at glyphosate doses from $160 \mathrm{~g}$ a.e. ha-1.

All herbicides applied in pre-emergence decreased the shoot dry matter of white leadtree plants (Figure 4A), although it is worth mentioning that for chlorimuron-ethyl, clomazone, flumioxazin, pendimethalin, sulfentrazone, and S-metolachlor, this reduction was less intense. On the other hand, regarding dry matter accumulation, postemergence application of chlorimuron-ethyl, clomazone, flumioxazin, haloxyfop-methyl, pendimethalin, and S-metolachlor did not differ from the control treatment (without herbicide). Thus, for postemergence application, although chlorimuronethyl, clomazone, and S-metolachlor provide symptoms of phytotoxicity, these symptoms do not imply lower dry matter accumulation.

Brancalion et al. (2009) found that the observed symptoms of toxicity and normal seedling development are signs that the selectivity of the tested herbicides to native forest species is due to the metabolization of the active ingredients, which progressively reduces their toxic action, not affecting the normal development of plants. Several studies show that pendimethalin (Marchi et al., 2018; Marques et al., 2019) and sulfentrazone (Monquero et al., 2011) did not reduce dry matter in native species, these herbicides being considered selective. In addition, Duarte et al. (2006) considered haloxyfop-methyl selective for aroeira.

Pre- and postemergence application of atrazine, indaziflam, and isoxaflutole led to shoot dry matter reductions of, respectively, 40.04 and $34.67 \%$; 30.66 and $36.36 \% ; 34.09$ and $42.48 \%$ (Figures $4 A$ and 4B). Marchi et al. (2018) and Marques et al. (2019), studying isoxaflutole, and Ferreira et al. (2005), studying atrazine, found that these herbicides decreased shoot dry matter in native species, demonstrating their nonselectivity. Shoot dry matter reductions were directly related to the levels of phytotoxicity provided by the herbicides to the studied plants.

Of the tested herbicides, glyphosate reduced shoot dry matter by $67.86 \%$, which shows the potential risk of using this herbicide in planting $L$. leucocephala. When simulating the drift effect of glyphosate (345.6 $\mathrm{g}$ a.e. ha-1) on eucalyptus, Tuffi Santos et al. (2005) found a decrease in dry matter. Monquero et al. (2011) and Yamashita et al. (2009) found a reduction in dry matter at glyphosate doses of 90 and $360 \mathrm{~g} \mathrm{ha}^{-1}$ a.e. in seedlings of native and forest species. In aroeira (Duarte et al., 2006) and lobeira (Machado et al., 2013), glyphosate was not considered selective. 
A 3 DAA שIIA 7 DAA $\triangle 1$ 14 DAA $Z 7 / 30$ DAA $\square 60$ DAA

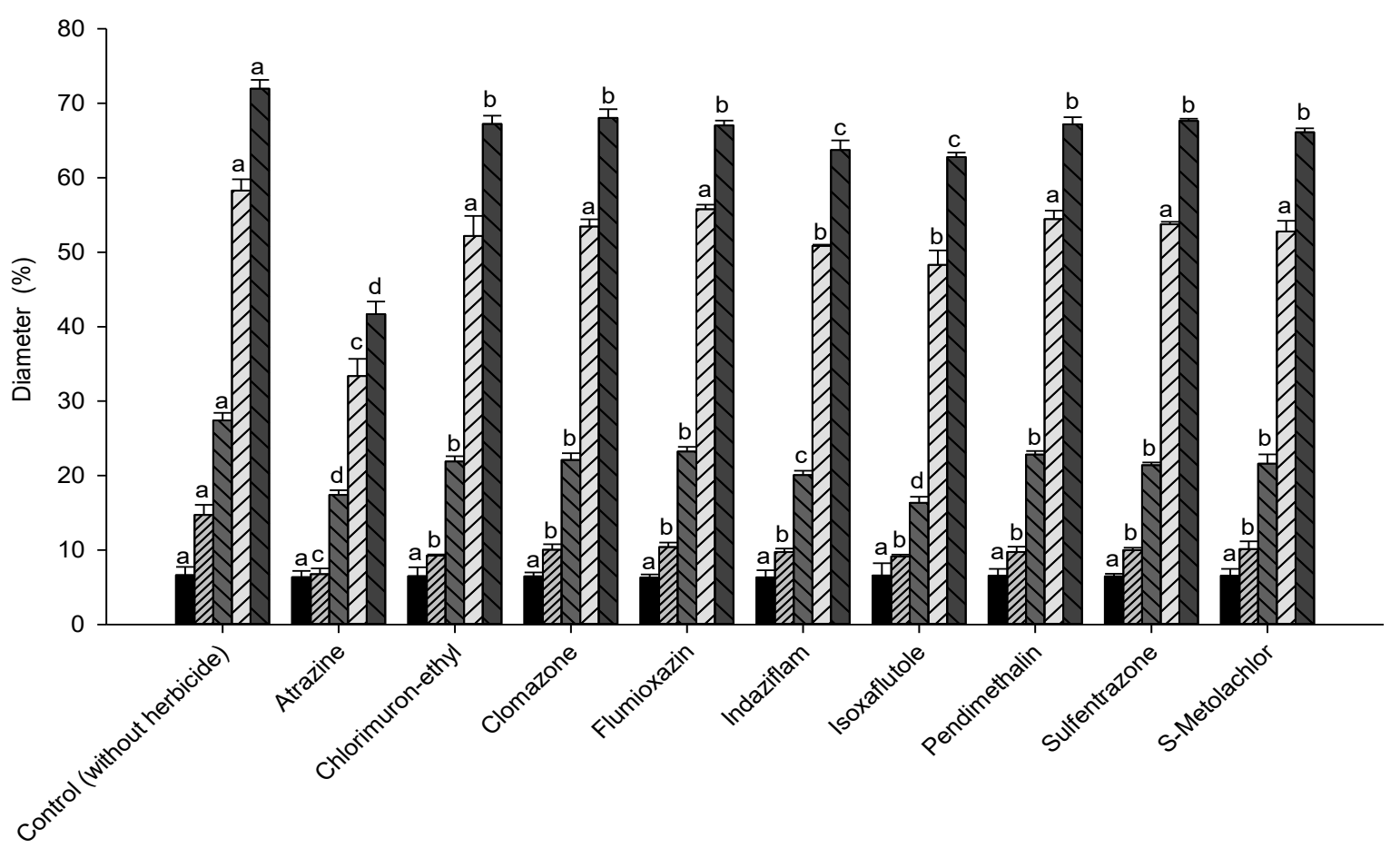

B

3 DAA שIIA 7 DAA $\triangle 14$ DAA $\square / \triangle 30$ DAA $\square 60$ DAA

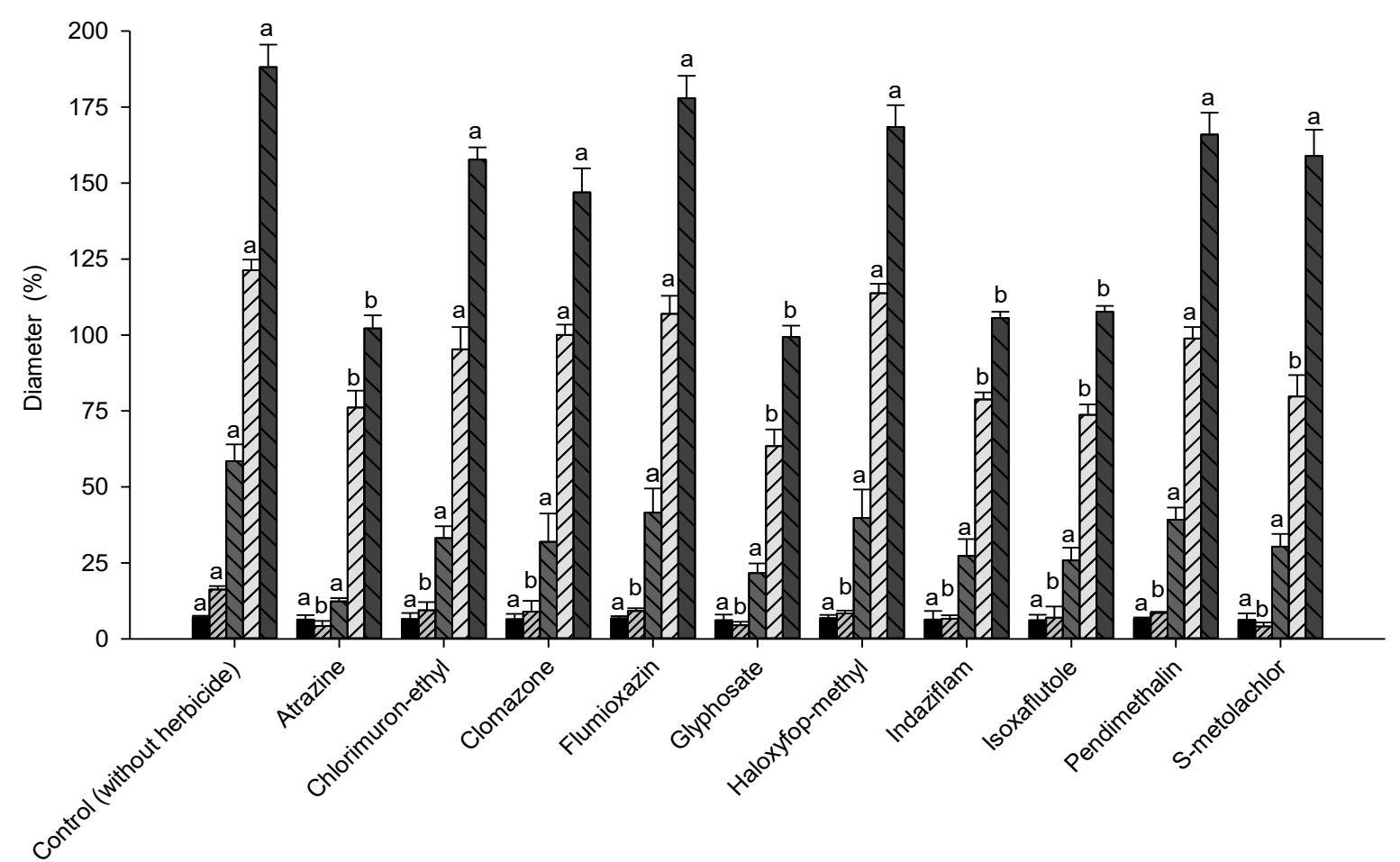

Figure 3 - Diameter (\%) of white leadtree (Leucaena leucocephala) seedlings under application of herbicides in pre (A) and post-emergence (B).

Means followed by the same letter in each column do not differ according to the Scott-Knott grouping criterion at $5 \%$ probability. Vertical bars represent the standard deviation of the means. 

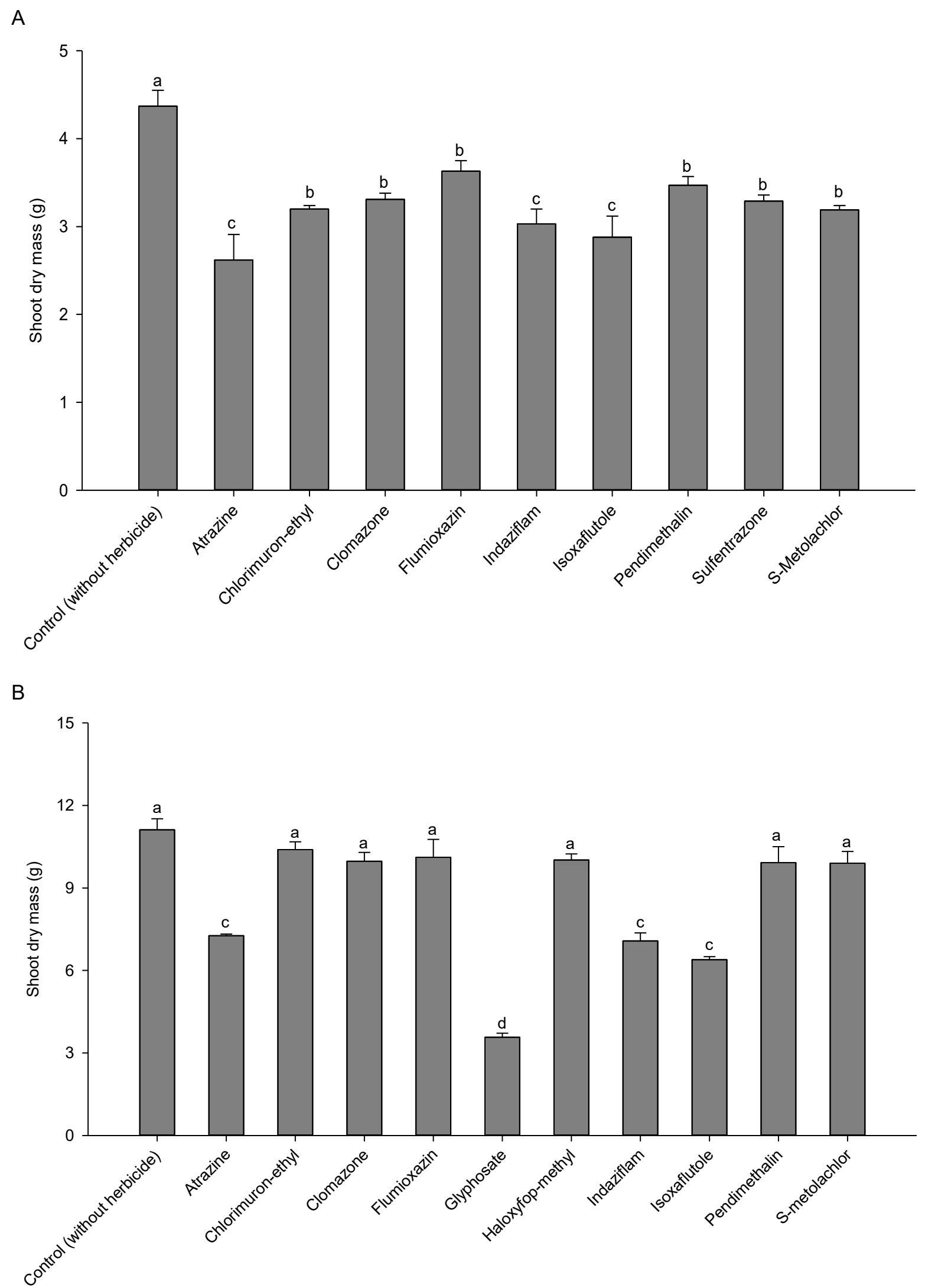

Figure 4 - Shoot dry mass of white leadtree (Leucaena leucocephala) seedlings under application of herbicides in pre (A) and post-emergence (B).

Means followed by the same letter in each column do not differ according to the Scott-Knott grouping criterion at $5 \%$ probability. Vertical bars represent the standard deviation of the means. 
The mechanism of action of the herbicide glyphosate is based on interrupting the pathway of the shikimic acid, preventing both the production of essential amino acids for protein synthesis and cell division in meristematic regions of the plant. Thus, this herbicide causes disturbances in the main metabolic pathways of plants, impairing their normal development (Tuffi Santos et al., 2005).

Damage varies according to the species' tolerance to glyphosate and the dose used. Moreover, it is recommended that this herbicide be applied in a targeted jet to avoid losses in plant development.

\section{Conclusions}

\begin{abstract}
Herbicides chlorimuron-ethyl, clomazone, flumioxazin, haloxyfop-methyl, pendimethalin, sulfentrazone, and S-metolachlor, applied in postemergence, were selective for $L$. leucocephala plants. In turn, herbicides atrazine, indaziflam, and isoxaflutole, applied in pre and postemergence, in addition to glyphosate, applied in postemergence, impaired the growth and development of white leadtree seedlings.
\end{abstract}

\section{Acknowledgements}

This study was financed in part by the Coordenação de Aperfeiçoamento de Pessoal de Nível Superior - Brasil (CAPES) - Finance Code 001. We also thank the National Research Council (CNPq) for the financial support for research through the Project (Process No. 140683/2018-6).

\section{References}

Brancalion PHS, Isernhagen I, Machado RP, Christoffoleti PJ, Rodrigues RR (2009) Seletividade dos herbicidas setoxidim, isoxaflutol e bentazon a espécies arbóreas nativas. Pesquisa Agropecuária Brasileira 44(3):251-257. doi: 10.1590/s0100$204 \times 2009000300005$.

Brighenti AM, Muller MD (2014) Controle do capimbraquiária associado à nutrição com boro no cultivo do mogno-africano em sistema silvipastoril. Revista Ciência Agronômica 45(4):745-751. doi: 10.1590/s180666902014000400012 .

Burnet MWM, Loveys BR, Holtum JAM, Powles SB (1993) A mechanism of chlorotoluron resistance in Lolium rigidum. Planta 190(2):182-189. doi: 10.2307/23382209.

Cabral CM, Dos Santos JB, Ferreira EA, Machado VM, Pereira IM, Silva DV, Souza MF (2017) Tolerance to the herbicide clomazone and potential for changes of forest species. Bioscience Journal 33(4):897-904.

Duarte NF, Karam D, Sá N, Cruz MB, Scotti MRM (2006) Seletividade de herbicidas sobre Myracrodruon urundeuva (AROEIRA). Planta Daninha 24(2):329337. doi: 10.1590/s0100-83582006000200016.
Embrapa (2013) Empresa Brasileira De Pesquisa Agropecuária. Sistema brasileiro de classificação de solos. 3. ed. Brasília, DF: Embrapa, 353p.

Ferreira DF (2008) Sisvar: um programa para análises e ensino de estatística. Revista Científica Symposium 6(2):36-41.

Ferreira RA, Davide AC, Alcântara EN De, Motta MS (2005) Efeito de herbicidas de pré-emergência sobre o desenvolvimento inicial de espécies arbóreas. Revista Brasileira de Herbicidas 4(1):133-145. doi: 10.7824/rbh.v4i1.17.

Letouzé A, Gasquez J (2003) Enhanced activity of several herbicide degrading enzymes: a suggested mechanism responsible for multiple resistance in blackgrass (Alopecurus myosuroides Huds.). Agronomie 23(7):601-608. Doi: 10.1051/agro:2003036.

Maciel CDG, Poletine JP, Alves IM, Raimondi MA, Rodrigues M, Bueno RR, Costa RS (2011) Coroamento no controle de plantas daninhas e desenvolvimento inicial de espécies florestais nativas. Semina: Ciências Agrárias 32(1):119-128. doi: 10.5433/16790359.2011v32n1p119.

Machado VM, Santos JB, Pereira IM, Lara RO, Cabral CM, Amaral CS (2013) Sensibilidade de mudas de espécies florestais nativas ao glyphosate. Bioscience Journal 29(6):1941-1951.

Marchi SR, Marques RF, Dos Santos Araújo PP, Marques AS, De Souza RM (2018) Ação de herbicidas pré-emergentes no estabelecimento inicial de plântulas de espécies nativas do Cerrado. Revista Brasileira de Herbicidas 17(4):e612-1. doi: 10.7824/rbh.v17i4.612.

Marques RF, Pinheiro GHR, Marques AS, De Souza RM, De Marchi SR (2019) Effect of pre-emergent graminicide herbicides on germination and early development of native species. Científica 47(1):28-35. doi: 10.15361/1984-5529.2019v47n1p28-35.

Monquero PA, Penha AS, Orzari I, Hirata ACS (2011) Seletividade de herbicidas em mudas das espécies nativas Acacia polyphylla, Enterolobium contortisiliquum (Fabaceae), Ceiba speciosa e Luehea divaricata (Malvaceae). Planta Daninha 29(1):159-168. doi: 10.1590/s0100-83582011000100018.

Oliveira JR RS (2011) Mecanismo de ação de herbicidas. In: Oliveira Junior RS, Constantin J, Inoue, MH (Ed.). Biologia e manejo de plantas daninhas. Curitiba: Omnipax, 2011. p. 141-192.

Paz L, Ferreira CH, Endres L, Nascimento HH, Souza RD (2018) Phytotoxic Effects of African Mahogany Seedlings to Herbicides. Floresta e Ambiente 25(4):2-7. doi: 10.1590/2179-8087.018617.

Santos LT, Ferreira FA, Meira RMSA, Barros NF, Ferreira LR, Machado AFL (2005) Crescimento e morfoanatomia foliar de eucalipto sob efeito de deriva do glyphosate. Planta Daninha 21(1):133-142. doi: 10.1590/s0100-83582005000100016. 
Scalon SPQ, Mussury RM, Rigoni MR, Veraldo F (2002) Crescimento de mudas de espécies florestais nativas sob diferentes níveis de sombreamento. Revista Árvore 29(1):1-5.

SBCPD (1995) Sociedade Brasileira Da Ciência Das Plantas Daninhas - Procedimentos para instalação, avaliação e análise de experimentos com herbicidas. Londrina: SBCPD, 1995. 42 p.

Souza MC, Da Costa Aguiar Alves PL, Salgado TP (2010) Interferência da comunidade infestante sobre plantas de Eucalyptus grandis de segundo corte. Scientia Forestalis 38(85):63-71.
Tiburcio RAS, Ferreira FA, Ferreira LR, Machado MS, Machado AFL (2012) Controle de plantas daninhas e seletividade do flumioxazin para eucalipto. Cerne 18(4):523-531. doi: 10.1590/s010477602012000400001.

Tuffi Santos LD, Ferreira FA, Meira RMSA, Barros NF, Ferreira LR, Machado AFL (2005) Crescimento e morfoanatomia foliar de eucalipto sob efeito de deriva do glyphosate. Planta Daninha 23(1):143-152.

Yamashita OM, Betoni JR, Guimarães SC, Espinosa MM (2009) Influência do glyphosate e 2,4-D sobre o desenvolvimento inicial de espécies florestais. Scientia Forestalis 37(84):359-366, 2009. 